\title{
ANALYSIS OF LANDSLIDES RISK IN DANO VILLAGE LELES DISTRICT GARUT REGENCY WEST JAVA
}

\author{
Fachry Arsyad \\ Bandung Social Welfare Polytechnic, fachryarsyad@gmail.com \\ Dede Kuswanda \\ Bandung Polytechnic of Social Welfare, dede_stks@yahoo.com \\ Milly Mildawati \\ Bandung Polytechnic of Social Welfare, millystks@gmail.com
}

\begin{abstract}
The study aims to obtain the overview of landslide risk in Dano Village, Leles District, Garut Regency. Disaster risk is the potential for losses arising from disasters. Level of disaster risk is the result of multiplication between threat and vulnerability divided by capability, meaning that the greater the threat and vulnerability while the smaller the capability, the greater the risk of disaster. The research method used a descriptive survey research methods with quantitative approaches. The research respondents were administrators and members of the Disaster Preparedness Village and Chairman of RW 06, 07 and 08 Kampung Patrol in total 46 respondents. Data collection techniques using a questionnaire. The results showed that in Dano Village, Leles Subdistrict, Garut Regency, there was a high category of landslide threat, a high category of vulnerability to landslides, and a low category of capability to encounter disaster threats. In general, Dano Village has a low level of disaster risk. Recommended research results are: a necessary effort to reduce the risk of landslides by depressing the threat of landslides, decreasing vulnerability to landslides, and increasing the capability on facing landslides. The next research recommendation is to examine the variable of preparedness to encounter the threat of landslides.
\end{abstract}

\section{Keywords:}

risks, disasters, landslides 


\section{INTRODUCTION}

The geological, geographical, hydrological and topographical conditions bring Indonesia into a potential and vulnerable area for frequently experiencing landslide disaster or ground movements. Geological condition makes Indonesia oftenly have earthquakes which can be a trigger for landslides or ground movements.

The geographical condition related to agricultural land management, which is not really concern about environmental aspect can be the reason of landslides occurs. Besides, the hydrological condition of Indonesia has two seasons, that is summer and rainy season. Landslide disaster generally occurs in the rainy season. This is also influenced by topographical condition or the earth's surface, Indonesian territory has a bumpy surface with part of the land is mountains and hills with steep slopes, which are very potential for landslides.

Badan Nasional Penanggulangan Bencana (BNPB) on Rancangan Aksi Nasional (RAN) Pengurangan Risiko Bencana (PRB) 2010-2012 has classificated district/city area based on the risk level of ground movement (landslides) into two category: (1) district/city that has a very high risk ground movement and (2) district/city that has a high risk ground movement. BNPB recorded that there are 90 districts/cities having a very high risk of ground movement threats and 93 districts/cities having a high risk of ground movement threats in Indonesia.

In West Java Province, the village that has a very high risk level area to experience a ground movement are Garut District, Cianjur District, Tasikmalaya District,
Sukabumi District, and West Bandung District. Meanwhile 2 of Bandung Districts, Bogor District, Ciamis District, Kuningan District, and Sumedang District has a high risk level of ground movement (BNPB, 2010).

In Garut District, the vulnerable area of having ground movement and landslides is Dano Village. This village is part of Leles Sub-district, Garut District, which topographically and geographically is hills area with bumpy surface and slightly steep slopes. This condition is very potential for landslides to occur. Apart from being hilly, the land surface in steep areas is only planted by little plants with strong roots. This also makes parts of Dano Village prone to landslides, especially during the rainy season.

People living in disaster-prone areas are threatened by danger at any time. In fact, they have to move or relocated to a place that is considered safe from the threat of disaster. But oftenly, relocation is not an easy thing to do. In some cases, even people who have been relocated will eventually return to their places of origin for several reasons. Indeed, relocation is not just moving people to a new place with new residence facilities, but also move their life and livelihoods.

If people living in disaster-prone areas choose to stay afloat, they must be able to adapt to conditions of disaster threat. They must not keep quiet about threats. The efforts to do such as a preventive action to keep the disaster never occur or at least reduce the threats of disaster. Although the threat cannot be prevented, then what must be done is to reduce the risk through mitigation activities. If the threat persists and 
the risk has been reduced, but there is a possibility of disaster, then the community must undertake preparedness. The activity that must be carried out before doing risk mitigation activities is conducting disaster risk analysis/assessment.

Disaster risk assessment is carried out by using the formula "disaster risk is the result of threat multiplied to vulnerability divided by capacity". In order to use this formula, it is necessary to know in advance the respective values of threats, vulnerabilities and capabilities in dealing with landslides.

According to the assessment result, furthermore, disaster prevention, mitigation, or preparedness and early warning activities can be carried out to reduce threats, decrease vulnerability, and increase capacity or capability to encounter the threat of landslides. This study aims to assess how much risk of landslides based on assessment of the Disaster Preparedness Village (DPV) administrators and members, so that the community has the data to be used as a basis for planning disaster risk reduction activities.

Disaster management activities generally intended to respond three disaster situation which are:

1) Before a disaster occurs or pre-disaster,

2) When a disaster occurs, and

3) Post disaster.

Activities that focused on the situation before a disaster occurs are called disaster risk reduction, activities when a disaster occurs are namely emergency response, and activities after a disaster or after an emergency response are known as recovery.
Disaster risk analysis is one of the stages in disaster risk reduction activities. Disaster risk analysis is an activity of assessing disaster risk to determine the amount of estimated losses that can be anticipated in specific areas during a specific time period (UNDP / UNDRO, 1992). Disaster risk analysis activities can use the formula "disaster risk equals to threat multiplied with vulnerability divided by capacity". So the size of disaster risk depends on the size of the threat value, vulnerability and capability. The formula for disaster risk (processed from: Disaster Management Education and Training Center, 2015, page 11) is as follows:

\begin{tabular}{|c|l|}
\hline H X V & DR = Disaster Risk \\
DR = Hazard \\
C & V = Vulnerability \\
& C = Capacity \\
\hline
\end{tabular}

Hazard (threat / danger) is an incident that can lead to disaster (RI Law, No. 24 of 2007). Another definition of a threat is a process, phenomenon or human activity that can cause death, injury or other health impacts, property damage, social and economic disruption or environmental degradation. Hazards can come from natural, anthropogenic, or natural sociological origins (UNISDR, 2016)

According to Sendai Framework For Disaster Risk Reduction 2015-2030, disaster threats can be grouped based on their origin, into: geological threats, hydrometerorological threats, biological threats, technological processes, phenomena and environmental damage. Geological 
threats such as earthquakes, including earthquakes that causing tsunamis, volcanic eruptions and landslides.

Besides, the hydrometeorological threat such as floods, including flash and tidal floods, hurricanes and storms (strong winds), drought, and lightning. While biological threats such as disease outbreaks and plant pests that cause harvest failure. Technological failure can be exemplified as a nuclear leak and for environmental damage can be shown as air, soil and water pollution.

Vulnerability is conditions which are determined by physical, social, economic and environmental factors/processes that increase susceptibility a community to the hazards impact (Affertranger, et al, 2007).

According to Coppola (2015, p. 33) "vulnerability is a measure of the propensity of an object, area, individual, group, community, country, or other entity to incur the consequences of a hazard". Physical vulnerability related to the condition of buildings that are prone to disasters, such as residential buildings, roads, bridges, office buildings, and others.

Meanwhile, social vulnerability is related to population condition in disasterprone areas who do not have the knowledge and skills to adapt to threats. While economic vulnerability is related to income, wealth or asset ownership which can be used for disaster handling including immediate recovery from a disaster. Environmental vulnerability is related to natural environmental conditions, such as steep slopes, bare land, etc. Capacity is the combination of all available strengths and resources in a community or institution that can reduce the level of risk or impact of a disaster (Affeltranger, 2007).
Resources can be used in disaster handling, both in disaster risk reduction phase during the emergency response and in the recovery period. Resources can be formed ad human resources, natural resources, financial resources, institutions, and others. Regarding the capability or capacity in disaster handling, Lopez, at all explained that "most people, event the poorest and most marginalized, have capacities (resources, network, knowledge, and skills) that they can put to work in order to prevent, resist, cope with, and recover from stress and shock such as hazardous natural events ".

The capabilities or capacities required in disaster management can be grouped into:

1) Human knowledge and skills in disaster handling;

2) Logistics to fulfill sufficient basic necessities for emergency and recovery period;

3) Facilities and equipments for risk reduction, emergency response, rehabilitation and reconstruction;

4) Institution for managing disaster handling activities;

5) Cooperation and networking.

Disaster risk is a potential loss caused by a disaster in an area and within a certain period of time, which such as a death, injury, illness, threat of life, loss of security, displacement, damage or loss of property, and disruption of community activities (Law No. 24 of 2007 ).

The size of a disaster risk is strongly influenced by the size of threat scale, the level of vulnerability on threats, and the level of ability to face or handle disasters. 
Disaster risk analysis result not only show the magnitude of disaster risk in a certain area and period of time, but also can produce the aspects value, even sub-aspects of threats, vulnerabilities and capacities. The results of disaster risk analysis can be used as basic data on carrying out disaster risk reduction activities, especially based on the lowest score of capability and the highest score of vulnerability.

Disaster risk analysis/assessment activity is one of the stages on disaster risk reduction. Type of disaster risk reduction activity depends on the results of risk assessment which refers to:

1) Assessment result of disaster threat

2) Assessment result of disaster vulnerability, and

3) Assessment result of capacity/capability on facing disasters.

Disaster risk reduction activities can be prioritized against high threats, high vulnerabilities and low capabilities/capacities.

Disaster risk reduction activities are carried out in disaster prone areas before the disaster occurs. Eliminating threats or reducing threats is one of the activities that needs to be carried out so that there are no more sources of disaster threats through prevention.

If the threat can not be prevented, then the next step is to reduce the risk of this threat through mitigation activities, and if the threat has been identified it will occur then preparedness and early warning must be done to all people who are probably affected as soon as possible to give a correct response.

Disaster risk reduction is a conceptual framework consisting of elements considered to have a possibility to minimize disaster vulnerability and risk throughout society, to avoid (prevent), or restrict (mitigation and preparedness) the adverse impacts caused by hazards (Afeltranger, et al. , 2007, p. 29).

The framework consist of following action sectors :

a. Risk awareness and assessment, including hazard analysis and vulnerability / capacity analysis;

b. Knowledge development, including education, training, research and information;

c. Public commitment and institutional framework, including institutional action, policies, laws and communities;

d. Implementation of action, including environmental management, land use and urban planning, protection of essential facilities, application of science and technology, partnerships and networks, and financial instruments;

e. Early warning systems include forecasting, warning dissemination, preparedness action, and capacity to give a reaction (Affeltranger, 2007, p. 30)

As the opinion of Afeltranger et al, generally there are four activities for disaster risk reduction called prevention, mitigation, preparedness, and early warning. Prevention is intended as an effort to minimize or eliminate threats, mitigation is intended to reduce disaster risk if such threats occur, while preparedness is intended to anticipate if a disaster occurs, and early warning is intended to make affected communities can save themselves and their belongings. The contents of introduction are the basic things or urgency of the problem as a background of study/research writing. 


\section{METHOD}

\section{Research Design}

The study aims to get an overview about the risk of landslides in Dano Village, Leles District, Garut Regency, therefore the research method used was descriptive method by a quantitative approach. According to Sugiyono (2012: 35) problem statement of a descriptive research is "a problem statement relating to question of the independent variable existence, either only on one variable or more (independent variable). This kind of research is called a descriptive research."

\section{Data Resources}

There are three categories of data resources used in the study, namely:

1. Data of general description about Dano Village obtained from Dano Village officers and documents about description of the village;

2. Data of landslides prone areas overview obtained from heads of Community Units (RW) in each area that are chairman of RW 06, chairman of RW 07, and chairman of RW 08; and

3. Data of threats, vulnerabilities, and capacities overview on facing landslides threat obtained from administrators and members of Disaster Preparedness Village in Dano Village, Leles District, Garut Regency.

\section{Population and Sample}

According to Neuman (2013: 207), population is an abstract idea of a large compilation of cases that researchers take samples on it, and the results of these samples are generalized. The population in this study is the administrators and members of Disaster Preparedness Village, Dano Village, Leles District, Garut Regency, in total number of 50 people. All administrators and members of $K S B$ were appointed as respondents, so the researchers did not determine sample.

At research proposal drafting stage, the number of respondents was determined to be 50 respondents, but at the time of data collection, the number of respondents who gave complete answers was only 46 respondents. Four people did not give complete answers, so the answers were not processed.

\section{Measuring and Analysis Instruments}

Research measuring instrument that used was an instrument such as a structured interview guide containing a list of questions or statements with available answer options. In this study, the measuring instrument used an ordinal measurement scale, which is a scale that differentiates the category levels or sequences of threats, vulnerabilities and capacities in dealing with landslides. The measurement scale that will be used to measure threats, vulnerability and capacity in dealing with landslides is "rating scale".

Each question or statement will use the following four answer options:

The Threat Aspect uses a level from "a little threatening" for a value of 1 , up to "very threatening" for a value of 4 . The Vulnerability Aspect uses a level from "slightly vulnerable" for a value of 1 , up to "very vulnerable" for a value of 4 . The Capacity Aspect uses the level from "less capable" for a value of 1 , up to "very capable", for a value of 4 .

The research data will be processed and presented in average number obtained from all respondents for each of threat, vulnerability and capacity aspects with the following categories: 
Very High: $3.26-4.00$

Height: $2.26-3.25$

Medium: $1.75-2.25$

Low: $1.00-1.7522$

\section{Validity and Reliability Test}

The measuring instruments will be tested for its validity and reliability to obtain valid and reliable measuring instruments. The validity testing uses construct validity test by constructing instrument according measured aspects based on the theory or formula for disaster risk, then consultated with experts.

Instrument reliability test was performed using split half technique from Spearman Brown, where the instrument items per variable were divided by two, then the two were connected using Spearmen Brown correlation formula. If the results of correlation analysis are $>=0.80$, the research instrument is stated reliable (Sarwono, 2015).

\section{Data Collection Technique}

1. Interview Technique Interview technique is a data collection technique by researchers asking questions to respondents according to the interview guidelines which have been prepared. Interview questions related to respondents assessments of threats, vulnerabilities and capacities in dealing with landslides.

2. Dokumentation Study Technique Documentation study technique is a data collection technique by collecting and studying documents that contain data on the description of Dano Village, Leles District, Garut Regency and disaster insident reports.

\section{Data Analysis Technique}

Interview data related to threats, vulnerabilities and capacities in dealing with landslides will be analyzed quantitatively. The research data will be processed and presented in a frequency distribution table, calculated with disaster formula, and categorized based on level of disaster risk, then analyzed and concluded.

The formula for disaster risk is "Disaster risk is the result from multiplication of threat and vulnerability divided by ability." To use this formula, it is necessary to make research data in numerical form (quantitatively) so that it can be calculated as the formula. Categories of disaster risk are divided into four, namely very high, high, medium, and low.

\section{RESEACH RESULT}

\section{Overview of Dano Village}

Dano Village is located in the western end of Leles District, with an area of 874,985 hectares, consisted of 4 hamlets with 8 Community Units (RW) and 32 Rukun Tetangga (RT). Dano Village has administrative area boundaries as follows:

North side: Jangkurang Village

East side: Lembang Village

South side: Tarogong District

West side: Bandung Village District

Dano is a village located in the slopes of Mount Guntur (local resident of Mount Gede) in the south, with an altitude range between 1200 - 1300 meters above sea level. Most of the Dano Village area is a mountain slope with a slope between 200 - 450. In the east, it is bordered by only natural fence boundary which is also the boundary to Lembang Village, Leles District and to the south, there is Ciharus River which is the 
administrative boundary to the Perhutani/ Mount Guntur area.

Hydrological aspect of a village area is really needed on controlling and regulating village water management. Based on its hydrology, the river flows in Dano village area form a watershed pattern, namely Curug Ciseeng watershed which is one of the Dano Village tourism potentials as well as a central watershed that flows into rivers and gutters. Several rivers and drains in small, medium and large scale, are located in Dano Village, namely: Ciharus River, Cigunung Agung River, Cisungalah River, Cigomong River, and Cihurang River.

Moreover, there are also several water springs that can be used as a source of clean water, as well as a source of water for agriculture. The main water springs which support the people of Dano Village are mostly from the mountainous area, namely the Ciseeng water spring. In general, lately there has been a decrease in the quality of rainfall and the amount of rain compared to the situation during previous years, this can be very influential on several water springs which are the source of community life both for household needs and for rice cultivators. Furthermore, this was also supported by uncontrolled damage of water springs resource due to lack of supervision from all related parties.

In general, the area in Dano Village is used as residential area, and only a small amount of it is used for productive area. However, this condition shows that Dano Village Area has adequate natural resources and is ready to be processed.

Although the land area is in the form of technical rice fields 25 ha, semi-technical 137 ha, rainfed 75 ha, yards/settlements of 9 ha, and others 6,815 ha. For more details regarding to land area and its use, please see table 1 below.

Table 1: Land Area by Type of Use at Dano Village in 2018

\begin{tabular}{|c|c|c|c|l|l|l|}
\hline $\begin{array}{c}\text { Rice } \\
\text { Field } \\
\text { s } \\
\text { (Ha) }\end{array}$ & \multicolumn{5}{|c|}{$\begin{array}{c}\text { Land } \\
\text { (Ha) }\end{array}$} \\
\hline $\begin{array}{c}1 / 2 \\
\text { Tech } \\
\text { nical }\end{array}$ & $\begin{array}{c}\text { Hang } \\
\text { overs }\end{array}$ & $\begin{array}{c}\text { Genera } \\
\text { Buildin } \\
\text { gs }\end{array}$ & $\begin{array}{c}\text { Settlemen } \\
\text { t } \\
\text { Prohibitio } \\
\text { ns }\end{array}$ & Pond & Grave & $\begin{array}{c}\text { Oth } \\
\text { ers }\end{array}$ \\
137 & 12 & 30 & 9 & 4,8 & 2,5 & \\
\hline
\end{tabular}

Based on the latest data from Population Census in 2010, the population of Dano Village was recorded at 10,175 people, but in 2014 about - People has increased every year by average of $2.4 \%$. For more details, see table 2 below.

Table 2: Total Population and Population Growth Rate of Dano Village in 2019

\begin{tabular}{|c|c|c|c|}
\hline No & Year & $\begin{array}{c}\text { Number of } \\
\text { Population }\end{array}$ & Growth Rate \\
\hline 1 & 2018 & 10.258 & $0,2 \%$ \\
\hline 2 & 2016 & 10.196 & $0,6 \%$ \\
\hline
\end{tabular}

The number of households in Dano Village in 2012 was 10,196 comuniholds/KK, in 2013 was 10,258 households/KK, in 2014 was 10,330 households/HH. The number of households in Dano Village in 2019 is 1365 households/KK. For more details, see table 3 below. 
Table 3: Number of Households Per Village and Community Units (RW) of Dano Village in 2019

\begin{tabular}{|c|c|c|c|c|}
\hline No & $\begin{array}{c}\text { RW/Village } \\
1\end{array}$ & $\begin{array}{c}\text { Numbe } \\
\text { r of } \\
\text { Househ } \\
\text { olds }\end{array}$ & $\begin{array}{c}\text { Density } \\
\text { per km } 2\end{array}$ & $\begin{array}{l}\text { Sex } \\
\text { Ratio }\end{array}$ \\
\hline 1 & 2 & 3 & 4 & 5 \\
\hline 1 & $\begin{array}{c}\text { RW } \\
\text { 01/Tambakb } \\
\text { aya }\end{array}$ & 398 & & \\
\hline 2 & $\begin{array}{c}\text { RW } \\
\text { 02/Tambakb } \\
\text { aya }\end{array}$ & 330 & & \\
\hline No & $\begin{array}{c}\text { RW/Village } \\
\text { II }\end{array}$ & $\begin{array}{c}\text { Numbe } \\
\text { r of } \\
\text { Househ } \\
\text { olds }\end{array}$ & $\begin{array}{c}\text { Density } \\
\text { per km } 2\end{array}$ & $\begin{array}{l}\text { Sex } \\
\text { Ratio }\end{array}$ \\
\hline 1 & 2 & 3 & 4 & 5 \\
\hline 3 & $\begin{array}{c}\text { RW } 03 \\
\text { Cibanen, } \\
\text { Cikondong, } \\
\text { Soreang }\end{array}$ & 423 & & \\
\hline 4 & $\begin{array}{c}\text { RW } 04 \\
\text { Cidampit, } \\
\text { Elos, } \\
\text { Kaluntang }\end{array}$ & 642 & & \\
\hline No & $\begin{array}{c}\text { RW/Village } \\
\text { III }\end{array}$ & $\begin{array}{c}\text { Numbe } \\
\text { r of } \\
\text { Househ } \\
\text { olds }\end{array}$ & $\begin{array}{c}\text { Density } \\
\text { per km } 2\end{array}$ & $\begin{array}{l}\text { Sex } \\
\text { Ratio }\end{array}$ \\
\hline 1 & 2 & 3 & 4 & 5 \\
\hline 1 & $\begin{array}{l}\text { RW 05, } \\
\text { Ciawitali, } \\
\text { Ciburial, } \\
\text { Palawija }\end{array}$ & & & \\
\hline 2 & $\begin{array}{c}\text { RW } \\
\text { 06/Dano }\end{array}$ & & & \\
\hline No & $\begin{array}{c}\text { RW/Village } \\
\text { IV }\end{array}$ & $\begin{array}{c}\text { Numbe } \\
\text { r of } \\
\text { Househ } \\
\text { olds }\end{array}$ & $\begin{array}{c}\text { Density } \\
\text { per km } 2\end{array}$ & $\begin{array}{l}\text { Sex } \\
\text { Ratio }\end{array}$ \\
\hline 1 & 2 & 3 & 4 & 5 \\
\hline 1 & $\begin{array}{c}\text { RW } \\
\text { 07/Patrol }\end{array}$ & 292 & & \\
\hline 2 & $\begin{array}{c}\text { RW } \\
\text { 08/Patrol }\end{array}$ & 300 & & \\
\hline & Total & 10.330 & & \\
\hline
\end{tabular}

Source : Data Desa Dano Book in 2018

The projection of Dano Village population in 2018 is 10,356 people, in 2019 the number is 10,391 . It means that in 2019 there was population increasing of 35 people, mostly due to birth factors.

\section{Respondent Characteristic}

Respondents for the study were the heads of Community Units (RW) 06, 07, and 08, administrators and members of the Disaster Preparedness Village, Dano Village, Leles District, Garut Regency. Total number of respondents was 46 respondents. Characteristics of respondents related to age, gender and level of formal education.

\section{Respondent Characteristic by Age}

Based on the age characteristics, the research respondents were in the range of 20 to 50 years. Respondents characteristic by age is presented in table 4 below:

Table 4 : Characteristics of Respondents by Age in Dano Village in 2019

\begin{tabular}{|c|c|c|c|}
\hline No & Age (Years) & $\mathrm{F}$ & $\%$ \\
\hline 1 & $20-30$ & 20 & 43,48 \\
\hline 2 & $31-40$ & 15 & 32,61 \\
\hline \multirow[t]{2}{*}{3} & $41-50$ & 11 & 23,91 \\
\hline & Total & 46 & 100,00 \\
\hline
\end{tabular}
respondents are working or in productive age. This means that apart from being a manager or member of the Kampung Siaga Bencana and as the head of Community Unit, respondent also does productive work in their respective fields of activity.

\section{Respondent Characteristic by Sex}

The concern of community members in disaster management is not only owned by men, but also by women. The characteristics 
of respondents based on gender are presented in table 5 below:

Table 5: Respondent Characteristics by Gender in 2019

\begin{tabular}{|c|l|c|c|}
\hline No & \multicolumn{1}{|c|}{ Gender } & F & $\%$ \\
\hline 1 & Male & 39 & 84,79 \\
\hline 2 & Female & 7 & 15,21 \\
\hline \multicolumn{2}{|c|}{ Total } & 46 & 100 \\
\hline
\end{tabular}

Table 5 shows that most of the respondents were male. Meaning that the involvement of women in Dano Village for disaster handling, especially in managing disaster handling activities through Disaster Preparedness Village is still lacking.

Characteristics of Respondents Based on Education

Education level represents someone's knowledge and ability both on general knowledge and specific knowledge as their field of study. Education level of respondents are presented on table 6 below:

Table 6 : Respondent Characteristic by Formal Education Level in 2019

\begin{tabular}{|c|l|c|c|}
\hline No & Education Level & F & $\%$ \\
\hline 1 & Elementary School & 27 & 58,9 \\
\hline 2 & Junior High School & 8 & 17,39 \\
\hline 3 & Senior High School & 7 & 15,22 \\
\hline 4 & Bachelor Degree & 4 & 8,70 \\
\hline \multicolumn{2}{|c|}{ Total } & 46 & 100,00 \\
\hline
\end{tabular}

As presented on Table 6, it is shown that some respondents have an education level on elementary school. It affects the ability to receive knowledge about disaster handling when sthrengtening required capacity for administrators and members of Disaster Preparedness Village is carried out.

\section{DISCUSSION}

\section{Overview of Landslides Threat}

The overview of data collection results about landslides threat in Dano
Village, Leles District, Garut Regency is based on the existence of objects that are likely to be affected if a landslide occurs. These objects are houses/residences, worship places, school buildings, road infrastructures, bridges, gardens, rice fields, fish ponds, electricity network facilities, livestock, mental safety, resident vehicles, school/study activities, work/livelihood activities and irrigation facilities. The score calculation of respondent answers to each statement item about the threat is carried out by adding up the multiplication results for each from respondent answers. The score is actual value obtained to describe the level of threatening to each statement item.

Category of threat level is determined based on calculation of the value position in interval class category. Category of interval class assigned by the determination of maximum value that may be obtained minus the minimum value that may be obtained divided by four interval classes as follows: 184 minus 46 obtained the number 138 is divided by 4 interval classes, then the result is 34. Therefore, the threat values and categories are as follows:

$$
\begin{array}{ll}
46-80: \text { low } & \\
81-115 & : \text { medium } \\
116-150 & : \text { high } \\
151-184 & \text { : very high }
\end{array}
$$

The results of scores calculation on respondent answers outcome about the threat of landslides to various objects around disaster-prone areas and threat level categories are presented in table 7 below:

Table 7: The results of scores calculation on respondent answers outcome about the threat of landslides and the category of threat level in Dano Village, Leles District, Garut Regency in 2019. 


\begin{tabular}{|c|c|c|c|}
\hline No & $\begin{array}{l}\text { Statement about } \\
\text { Landslides Threat }\end{array}$ & Score & $\begin{array}{l}\text { Category } \\
\text { of Threat }\end{array}$ \\
\hline 1 & 2 & 3 & 4 \\
\hline 1 & $\begin{array}{l}\text { Landslides threat on } \\
\text { residences in Dano } \\
\text { Village Leles District } \\
\text { Garut Regency in } \\
2019 .\end{array}$ & 142 & High \\
\hline 2 & $\begin{array}{l}\text { Landslides threat on } \\
\text { worship places (surau, } \\
\text { mosque, etc) in Dano } \\
\text { Village Leles District } \\
\text { Garut Regency in } \\
2019 \text {. }\end{array}$ & 154 & $\begin{array}{l}\text { Very } \\
\text { High }\end{array}$ \\
\hline 3 & $\begin{array}{l}\text { Landslides threat on } \\
\text { school in Dano Village } \\
\text { Leles District Garut } \\
\text { Regency in } 2019 .\end{array}$ & 106 & Medium \\
\hline 4 & $\begin{array}{l}\text { Landslides threat on } \\
\text { road infrastructures in } \\
\text { Dano Village Leles } \\
\text { District Garut Regency } \\
\text { in } 2019\end{array}$ & 132 & High \\
\hline 1 & 2 & 3 & 4 \\
\hline 5 & $\begin{array}{l}\text { Landslides threat on } \\
\text { general infrastructure } \\
\text { as bridges in Dano } \\
\text { Village Leles District } \\
\text { Garut Regency in } 2019\end{array}$ & 110 & Medium \\
\hline 6 & $\begin{array}{l}\text { Landslides threat on } \\
\text { agriculture land such as } \\
\text { gardens in Dano } \\
\text { Village Leles District } \\
\text { Garut Regency in } 2019\end{array}$ & 172 & $\begin{array}{l}\text { Very } \\
\text { High }\end{array}$ \\
\hline 7 & $\begin{array}{l}\text { Landslides threat on } \\
\text { agriculture land such as } \\
\text { rice field in Dano } \\
\text { Village Leles District } \\
\text { Garut Regency in } 2019\end{array}$ & 130 & High \\
\hline 8 & $\begin{array}{l}\text { Landslides threat on } \\
\text { fish pond in Dano } \\
\text { Village Leles District } \\
\text { Garut Regency in } 2019\end{array}$ & 108 & Medium \\
\hline 9 & $\begin{array}{l}\text { Landslides threat on } \\
\text { clean water facilities in } \\
\text { Dano Village Leles } \\
\text { District Garut Regency } \\
\text { in } 2019\end{array}$ & 150 & High \\
\hline 10 & Landslides threat on & 128 & High \\
\hline
\end{tabular}

\begin{tabular}{|c|c|c|c|}
\hline & $\begin{array}{lr}\text { electricity } & \text { network } \\
\text { facilities in } & \text { Dano } \\
\text { Village Leles District } \\
\text { Garut Regency in } 2019\end{array}$ & & \\
\hline 11 & $\begin{array}{l}\text { Landslides threat on } \\
\text { livestock in Dano } \\
\text { Village Leles District } \\
\text { Garut Regency in } 2019\end{array}$ & 136 & High \\
\hline 12 & $\begin{array}{l}\text { Landslides threat on } \\
\text { life savety in Dano } \\
\text { Village Leles District } \\
\text { Garut Regency in } 2019\end{array}$ & 134 & High \\
\hline 13 & $\begin{array}{l}\text { Landslides threat on } \\
\text { residents vehicels in } \\
\text { Dano Village Leles } \\
\text { District Garut Regency } \\
\text { in 2019in Dano Village } \\
\text { Leles District Garut } \\
\text { Regency in } 2019\end{array}$ & 136 & High \\
\hline 14 & $\begin{array}{l}\text { Landslides threat on } \\
\text { school activities in } \\
\text { Dano Village Leles } \\
\text { District Garut Regency } \\
\text { in } 2019\end{array}$ & 128 & High \\
\hline 15 & $\begin{array}{l}\text { Landslides threat on } \\
\text { work activities in Dano } \\
\text { Village Leles District } \\
\text { Garut Regency in } 2019\end{array}$ & 142 & High \\
\hline 16 & $\begin{array}{l}\text { Landslides threat on } \\
\text { irrigation facilities in } \\
\text { Dano Village Leles } \\
\text { District Garut Regency } \\
\text { in } 2019\end{array}$ & 122 & High \\
\hline & Total & 2130 & High \\
\hline
\end{tabular}

The categories of threats to Dano Village residents who live in landslides prone areas are grouped into four categories. The threat categories are as follows

$$
\begin{array}{ll}
736-1288 & : \text { low } \\
1289-1841 & : \text { medium } \\
1842-2394 & : \text { high } \\
2395-2944 & \text { : very high }
\end{array}
$$

Those threat categories are obtained by calculating the minimum (736) and maximum (2944) possible scores. After that, the maximum score is deducted by the 
minimum score, and the result is divided by the number of interval classes (552), which is four.

The calculation results of of respondent answers about threats to people living in disaster-prone areas obtained a total score of 2130. This number shows the threat is in high category.

Table 7 shows that most or about 12 objects threatened by landslides in Dano Village are categorized as high threat, in fact threats to worship places and agricultural land are categorized as very high, only two objects which are bridges and fish ponds owned by residents are likely to be threatened with a medium threat category.

In general, the threat of landslides in Dano Village is in category high (score 2,130). The condition indicates that landslides threat in Dano Village can pose a risk such as high losses, both material and non-material. The high threat of landslides can be affected by:

1) Strength, breadth and speed of landslides to hit objects above or below the slope of soil surface;

2) The proximity of objects that are potentially to be hit or carried away by landslides with the source of landslides.

\section{Overview of Vulnerability to Landsides}

The overview of data collection result on vulnerability to landslides in Dano Village, Leles District, Garut Regency is based on the existence of objects that are likely to be affected if a landslide occurs. These objects are houses/ living places, worship places, school buildings, road infrastructure, bridges, gardens, rice fields, fish ponds, electricity network facilities, livestock, life safety, residents vehicles, school/study activities, work/livelihood activities. , and irrigation facilities.

The overview of object's

vulnerability to landslides is assessed based on the potential of objects to be affected in disaster-prone areas. Objects that potentially to be affected by landslides in Dano Village are: residences, worship places, school buildings, road infrastructure, bridges, gardens, rice fields, fish ponds, electricity network facilities, livestock, life safety, residents vehicles, school/learning activities , work/livelihood activities, and irrigation facilities.

Score calculation of respondent answer to each statement item regarding vulnerability is assessed by adding the multiplication results for each choice of respondent answer. The score is actual value obtained to describe the level of vulnerability in each statement item.

The category of vulnerability level is determined based on the calculation of the value position in interval class category. Category of interval class assigned by the determination of maximum value that may be obtained minus the minimum value that may be obtained divided by four interval classes as follows: 184 minus 46 , the number 138 is divided by 4 interval classes, then the result is 34 . Therefore, the values and categories of vulnerability are as follows:

$$
\begin{array}{ll}
46-80 & : \text { Low } \\
81-115 & : \text { Medium } \\
116-150 & : \text { High } \\
151-184 & : \text { Very High }
\end{array}
$$

The results of scores calculation on respondent answers outcome about objects vulnerability to landslides around disasterprone areas and the level of vulnerability are presented in table 8 below: 
Table 8: The results of scores calculation on respondent answers outcome about vulnerability to landslides and its category of vulnerability in Dano Village, Leles District, Garut Regency in 2019.

\begin{tabular}{|c|c|c|c|}
\hline No & $\begin{array}{lr}\text { Statement } & \text { about } \\
\text { Vulnerability } & \text { to } \\
\text { Landslides } & \end{array}$ & Score & $\begin{array}{l}\text { Cathegory of } \\
\text { Vulnerability }\end{array}$ \\
\hline 1 & 2 & 3 & 4 \\
\hline 1 & $\begin{array}{l}\text { Vulnerability of } \\
\text { residences caused by } \\
\text { landslides in Dano } \\
\text { Village } \\
\text { District Leles } \\
\text { Regency in } 2019 .\end{array}$ & 132 & High \\
\hline 2 & $\begin{array}{l}\text { Vulnerability } \\
\text { worship places/ } \\
\text { mosque caused by } \\
\text { ladnslides in Dano } \\
\text { Village } \\
\text { District } \\
\text { Regency in 2019. }\end{array}$ & 104 & Medium \\
\hline 3 & $\begin{array}{l}\text { Vulnerability of } \\
\text { school buildings } \\
\text { caused by ladnslides } \\
\text { in Dano Village } \\
\text { Leles District Garut } \\
\text { Regency in } 2019 .\end{array}$ & 114 & Medium \\
\hline 4 & $\begin{array}{l}\text { Vulnerability of road } \\
\text { infrastructures } \\
\text { caused by ladnslides } \\
\text { in Dano Village } \\
\text { Leles District Garut } \\
\text { Regency in } 2019 .\end{array}$ & 132 & Medium \\
\hline 5 & $\begin{array}{l}\text { Vulnerability of } \\
\text { bridges caused by } \\
\text { ladnslides in Dano } \\
\text { Village } \\
\text { District Leles } \\
\text { Regency in 2019. }\end{array}$ & 104 & Medium \\
\hline 6 & $\begin{array}{l}\text { Vulnerability of } \\
\text { agricultural land } \\
\text { such as gardens } \\
\text { caused by ladnslides } \\
\text { in Dano Village } \\
\text { Leles District Garut } \\
\text { Regency in 2019. }\end{array}$ & 136 & High \\
\hline 7 & Vulnerability of & 130 & High \\
\hline
\end{tabular}

\begin{tabular}{|c|c|c|c|}
\hline & $\begin{array}{l}\text { agricultural land } \\
\text { such as rice fields } \\
\text { caused by ladnslides } \\
\text { in Dano Village } \\
\text { Leles District Garut } \\
\text { Regency in } 2019 .\end{array}$ & & \\
\hline 8 & $\begin{array}{l}\text { Vulnerability of fish } \\
\text { pond caused by } \\
\text { ladnslides in Dano } \\
\text { Village } \\
\text { District Leles } \\
\text { Regency in } 2019 \text {. }\end{array}$ & 134 & High \\
\hline 9 & $\begin{array}{l}\text { Vulnerability of } \\
\text { water spring caused } \\
\text { by ladnslides in } \\
\text { Dano Village Leles } \\
\text { District Garut } \\
\text { Regency in } 2019 .\end{array}$ & 142 & High \\
\hline 1 & 2 & 3 & 4 \\
\hline 10 & $\begin{array}{l}\text { Vulnerability of } \\
\text { electricity } \\
\text { network/installation } \\
\text { caused by ladnslides } \\
\text { in Dano Village } \\
\text { Leles District Garut } \\
\text { Regency in 2019. }\end{array}$ & 134 & Very High \\
\hline 11 & $\begin{array}{l}\text { Vulnerability } \\
\text { livestock caused by } \\
\text { ladnslides in Dano } \\
\text { Village } \\
\text { District Leles } \\
\text { Regency in } 2019 .\end{array}$ & 154 & Very High \\
\hline 12 & $\begin{array}{l}\text { Vulnerability of life } \\
\text { savety caused by } \\
\text { ladnslides in Dano } \\
\text { Village } \\
\text { District Leles } \\
\text { Regency in } 2019 .\end{array}$ & 154 & Very High \\
\hline 13 & $\begin{array}{l}\text { Vulnerability of } \\
\text { residents vehicles } \\
\text { caused by ladnslides } \\
\text { in Dano Village } \\
\text { Leles District Garut } \\
\text { Regency in } 2019 .\end{array}$ & 162 & Very High \\
\hline 14 & $\begin{array}{l}\text { Vulnerability of } \\
\text { school activities } \\
\text { caused by ladnslides } \\
\text { in Dano Village } \\
\text { Leles District Garut }\end{array}$ & 162 & Very High \\
\hline
\end{tabular}




\begin{tabular}{|l|l|l|l|}
\hline 15 & Regency in 2019. & & \\
\hline & $\begin{array}{l}\text { Vulnerability of } \\
\text { working activities } \\
\text { caused by ladnslides } \\
\text { in Dano Village } \\
\text { Leles District Garut } \\
\text { Regency in 2019. }\end{array}$ & High \\
\hline 16 & $\begin{array}{l}\text { Vulnerability of } \\
\text { irrigation } \\
\text { infrastructures } \\
\text { caused by ladnslides } \\
\text { in Dano Village } \\
\text { Leles District Garut } \\
\text { Regency in 2019. }\end{array}$ & High \\
\hline & Jumlah & 2176 & High \\
\hline
\end{tabular}

The categories of vulnerability for Dano Village community who live in landslides prone area are grouped into four categories. This is appropriate with the possible values obtained by respondents for answers related to the capability of disaster handling. The categories of vulnerability are as follows:

$$
\begin{array}{ll}
736-1288 & : \text { Low } \\
1289-1841 & : \text { Medium } \\
1842-2394 & : \text { High } \\
2395-2944 & : \text { Very High }
\end{array}
$$

The vulnerability category is obtained by calculating the minimum (736) and maximum (2944) possible scores. Then the maximum score is deducted by the minimum score, and the result is divided by the number of interval classes (552), which is four.

The calculation result of respondent answers regarding vulnerability of people living in disaster-prone areas obtained a total score of 2176. It means that vulnerability is in high category. Table 8 shows that generally objects that are likely to be affected by landslides, have a high level of vulnerability ( 9 objects), there are even four objects whose vulnerability is in very high category, namely: resident livestock, life safety, resident vehicles, and student learning activities. Only three objects categorized into the medium vulnerability which are worship places, schools, and bridges.

In general, the level of vulnerability to landslides in Dano Village is in the high category (score 2.176).

\section{Overview of Capability to Encounter Landslide Disaster}

An overview of data collection results on the capacity/capability to encounter landslide disaster in Dano Village, Leles District, Garut Regency is related to the various resources to be used in dealing with the threat of disaster. These resources include: knowledge, economy, equipment, logistic, and the ability to recover from disasters of the community's capability, Disaster Preparedness Village organization, and the capability of village government.

The score calculation of respondents answer to each statement item about capability is carried out by adding up the multiplication results for each choice according to the respondents answer. This score is the actual value obtained to describe the capability level of each statement item.

Category of capability level is determined based on calculation of the value position in interval class category. Category of interval class assigned by the determination of maximum value that may be obtained minus the minimum value that may be obtained divided by four interval classes as follows: 184 minus 46, the number 138 is divided by 4 interval classes, 
then the result is 34 Therefore, the scores and ability categories are as follows:

$$
\begin{aligned}
& 46-80: \text { Low } \\
& 81-115: \text { Medium }
\end{aligned}
$$

$$
\begin{array}{ll}
116-150 & : \text { High } \\
151-184 & : \text { Very High }
\end{array}
$$

The score calculating result on the results of respondent answers regarding the ability to face landslides threat and the category of capability levels in Dano Village are presented in table 9 below:

Table 9: The results of the score calculation on respondent answers outcome regarding the ability to face the threat of landslides and

\begin{tabular}{|c|c|c|c|}
\hline No & $\begin{array}{l}\text { Capability/Capacity } \\
\text { to Encounter } \\
\text { Landslides }\end{array}$ & Score & $\begin{array}{c}\text { Cathegory of } \\
\text { Capability/ } \\
\text { Capacity }\end{array}$ \\
\hline 1 & 2 & 3 & 4 \\
\hline 1 & $\begin{array}{l}\text { Capability } \\
\text { residents } \\
\text { knowledge } \\
\text { encounter } \\
\text { landslides in } \\
\text { Village } \\
\text { District } \\
\text { Regency in } 2019 \text {. }\end{array}$ & 76 & Low \\
\hline 2 & $\begin{array}{lr}\begin{array}{l}\text { Capability } \\
\text { village }\end{array} & \begin{array}{r}\text { of } \\
\text { officers }\end{array} \\
\text { knowledge } & \text { to } \\
\text { encounter } & \\
\text { landslides in Dano } \\
\text { Village } \\
\text { District } \\
\text { Regency in } & \text { Geles } \\
\text { Rarut }\end{array}$ & 98 & Medium \\
\hline 3 & $\begin{array}{l}\text { Knowledge } \\
\text { capability } \\
\text { Kampung } \\
\text { Bencana } \\
\text { administrators and } \\
\text { members } \\
\text { encounter } \\
\text { landslides in } \\
\text { Village }\end{array}$ & 104 & Medium \\
\hline
\end{tabular}
the category of capability levels in Dano

\begin{tabular}{|c|c|c|c|}
\hline & $\begin{array}{l}\text { District Garut } \\
\text { Regency in } 2019 .\end{array}$ & & \\
\hline 4 & $\begin{array}{lr}\text { Economic } & \text { (cost) } \\
\text { capability } & \text { of } \\
\text { residents } & \text { to } \\
\text { encounter } & \\
\text { landslides } & \\
\text { Village } & \text { Dano } \\
\text { District } & \text { Leles } \\
\text { Regency in } & \text { Garut } \\
\end{array}$ & 94 & Medium \\
\hline 5 & $\begin{array}{l}\text { Economic } \\
\text { capability (cost) of } \\
\text { village government } \\
\text { to encounter } \\
\text { landslides in Dano } \\
\text { Village Leles } \\
\text { District Garut } \\
\text { Regency in } 2019 .\end{array}$ & 98 & Medium \\
\hline 6 & $\begin{array}{l}\text { Economic } \\
\text { capability (cost) of } \\
\text { Disaster } \\
\text { Preparedness } \\
\text { Village to } \\
\text { encounter } \\
\text { landslides in Dano } \\
\text { Village Leles } \\
\text { District Garut } \\
\text { Regency in } 2019 .\end{array}$ & 63 & Low \\
\hline 7 & $\begin{array}{l}\text { Equipment capacity } \\
\text { of residents to } \\
\text { encounter } \\
\text { landslides in Dano } \\
\text { Village Leles } \\
\text { District Garut } \\
\text { Regency in } 2019 .\end{array}$ & 86 & Medium \\
\hline 8 & $\begin{array}{l}\text { Equipment capacity } \\
\text { of } \\
\text { government } \\
\text { encounter } \\
\text { landslides in } \\
\text { Village } \\
\text { District } \\
\text { Regency in } 2019 .\end{array}$ & 106 & Medium \\
\hline 9 & $\begin{array}{l}\text { Equipment capacity } \\
\text { of Village Alert } \\
\text { Disaster } K S B \text { to } \\
\text { encounter } \\
\text { landslides in Dano } \\
\text { Village Leles }\end{array}$ & 93 & Medium \\
\hline
\end{tabular}
Village, Leles District, Garut Regency in 2019. 


\begin{tabular}{|c|c|c|c|}
\hline & $\begin{array}{l}\text { District Garut } \\
\text { Regency in } 2019 .\end{array}$ & & \\
\hline 10 & $\begin{array}{l}\text { Logistic capacity of } \\
\text { residents } \\
\text { encounter } \\
\text { landslides in } \\
\text { Village } \\
\text { District } \\
\text { Regency in } 2019 .\end{array}$ & 95 & Medium \\
\hline 11 & $\begin{array}{l}\text { Logistic capacity of } \\
\text { village government } \\
\text { to encounter } \\
\text { landslides in Dano } \\
\text { Village } \\
\text { District Leles } \\
\text { Regency in } 2019 .\end{array}$ & 104 & Medium \\
\hline 12 & \begin{tabular}{l}
\multicolumn{2}{l}{ Logistic capacity of } \\
Kampung Siaga \\
Bencana KSB to \\
encounter \\
landslides in Dano \\
Village \\
District \\
Regency in 2019.
\end{tabular} & 90 & Medium \\
\hline 13 & $\begin{array}{lr}\text { Capability } & \text { of } \\
\text { disaster victims to } \\
\text { recover } & \text { from } \\
\text { landslides in } & \text { Dano } \\
\text { Village } & \text { Leles } \\
\text { District } & \text { Garut } \\
\text { Regency in } & 2019 .\end{array}$ & 97 & Medium \\
\hline 14 & $\begin{array}{lr}\text { Capability } & \text { of } \\
\text { village government } \\
\text { to recover from } \\
\text { landslides in Dano } \\
\text { Village } \\
\text { District } \\
\text { Regency in } 2019 .\end{array}$ & 100 & Medium \\
\hline 1 & 2 & 3 & 4 \\
\hline 15 & 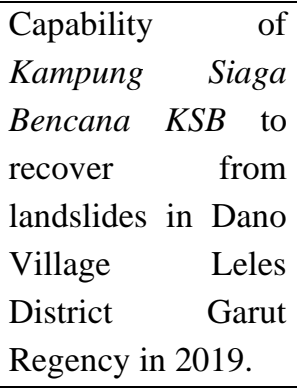 & 102 & Medium \\
\hline & Total & 1406 & Medium \\
\hline
\end{tabular}

The category of community capability, Disaster Preparedness Village, and the Dano Village government in landslides handling can be grouped into four categories. This is in accordance with the possible values obtained by respondents for related answers to capability in disaster handling.

The cathegories of capacity are :

690 - 1207 : Low

$1208-1752$ : Medium

$1753-2243$ : High

$2244-2760$ : Very High

Category of capability is obtained by calculating the minimum (690) and maximum (2760) possible scores. Then the maximum score is reduced by the minimum score, and the result is divided by the number of interval classes (517), which is four.

The calculation result of the respondent answers regarding capability in disaster handling obtained a total score of 1.406. This number shows the capability is in medium category.

In table 9, it can be seen from 15 aspects of capabilities that must be had in dealing with landslides, about 13 aspects are in the medium category, and two aspects are included in low category which are:

1) Public knowledge in facing the threat of landslides, and

2) The economic capability (cost) of Disaster Preparedness Village organization, in fact $K S B$ organization is the only organization in Dano Village area that has duties and functions of disaster handling in village level.

The inadequate capability to encounter landslide threats will potentially 
create huge losses when a land disaster occurs, whether it is loss of property, life, environment, or disruption to community activities.

\section{Result of Disaster Risk Analysis}

The magnitude landslides risk in Dano Village itself is determined by three factors, namely the threat of landslides, vulnerability to landslides, and the capability to encounter landslides. Referring to this, the results of data collection, processing and analysis to measure the amount of Landslide Disaster Risk in Dano Village, Leles District, Garut Regency are calculated using the disaster risk formula, which is the threat multiplied by vulnerability divided by capability. After that, four risk categories are made, namely very high, high, medium, and low. The possible average value intervals are:

$$
\begin{array}{ll}
\text { Low } & : 0,25-4,19 \\
\text { Medium } & : 4,20-8,29 \\
\text { High } & : 8,30-12,49 \\
\text { Very High } & : 12,50-16,00
\end{array}
$$

The calculation result of respondent answers for the threat aspect obtained a total value of 2,130 or an average of 2.90, for the vulnerability aspect obtained a total value of 2.176 or an average of 2.95 , while the result obtained for capability aspect were 1.406 or an average of 2.04. Therefore, the magnitude of disaster risk is 2.90 multiplied by 2.95 then divided by 2.04 which equals 4.19 . The value of 4.19 is in the low category, tends to the medium category.

Based on the calculation result, here is a further explanation regarding the factors related to disaster risk in Dano Village. First, the threat factor has a huge influence to the high risk of disaster.
From the results of collecting and calculating specific data related to the threat of landslides in Dano Village obtained number which indicated that the threat of landslides in Dano Village was in high category. There are several factors that can affect a high threat of landslides, namely:

1) Related to the source of threat and

2) The existence of objects that may be affected by the threat.

The factors causing the high threat of landslides are related to the source of threat which are:

1) The extent of area that make an opportunity to occur landslides, meaning that the wider the area of landslides, the wider the areas and objects that are possible to be affected by landslides;

2) The slope degree of hill or mountain slope, meaning that the higher the slope degree, the greater the threat;

3) The absence of landslide barriers or soil binders on the surface of slopes which can inhibit landslides, such as embankments, terraces, and strong rooted trees.

The factors causing the high threat of landslides are related to the presence of objects that may be affected by the threat such as:

1) The number of people who live in landslides prone areas,

2) Property belonging to residents in landslides prone areas;

3) The number of facilities and infrastructure in landslides prone areas;

4) Natural environmental conditions that are possible to be affected by landslides; andThe number of activities and various 
types of services in landslides prone areas.

This also match with Noor (2014) opinion, where the magnitude of threat is determined by the possible duration, place or location, and the nature of incident.

In addition, the high threat of landslides in Dano Village has various impacts to the life and livelihoods of people living in disaster-prone areas, such as:

1) Life safety of the community,

2) Damage and/or loss of property;

3) Loss of livelihood,

4) Disruption of public services and social activities;

5) Natural environment damage,

6) Facilities and infrastructure damage, etc.

Second, related to the vulnerability factor, the results of data collection and calculation for vulnerability to landslides in Dano Village, obtained the indication that vulnerability to landslides in Dano Village is also in the high category.

Refers to Chambers statement on Nasikun (2001), vulnerability is reflection of a condition without back up or reserve to handle unexpected things.

In connection with Chambers statement, the high result of vulnerability scoring in Dano Village make these objects are easily affected if a landslide occurs, and the Dano community also does not have the back up or preparation to deal with this. To encounter this condition, various efforts are needed to reduce the vulnerability, because if vulnerability meets a threat, the resulting loss or risk will increase.

There are several factors that causing the high rate of vulnerability to landslides in Dano Village, such as:
1) The distance between object and the source of the threat, the closer object to the source of threat, the higher the vulnerability

2) Lack of knowledge of the people living in landslide prone areas about disaster risk reduction; and

3) Strength of buildings and infrastructure in langslides prone areas. The high rate of vulnerability to landslides threat in Dano Village will impact on the high risk of disasters. The threat is high when meet with high vulnerability, then it is definitely the risk will be high.

This means that if a landslide occurs, the damage and losses to the people will be high. So, efforts are needed to reduce or decrease vulnerability.

The third factor, related to the capabilities on facing the threat of landslides in Dano Village, has also been obtained number which show that the capabilities to face landslides threat in Dano Village is in low category.

The capabilities are such as knowledge capability, economic capability, the capability of equipment needed for disaster handling, logistic capability in emergency situation, and the ability to recover after a disaster occurs. The low capability landslides handling can be influenced by several factors.

Lack of capability in knowledge aspect can be affected by the fact that people has not received socialization or counseling or training about landslide disaster handling.

The lack of capability of the community in economic aspect for disaster handling can be affected by low income and assets. The lack of capacity regarding logistics, equipments and recovery capability 
is very influenced by their economic condition including the assets they have.

The low capability in disaster handling of landslides in Dano Village, both the capability of community and capability of the Disaster Preparedness Village, and also the capability of the Dano Village government affecting the high risk of disaster. If a landslide occurs in Dano Village, it will pose a risk to life safety of residents, environmental damage, loss of property and livelihoods, and psycho social impacts.

This is convinced by the statement of Khambali (2017) which is the relationship between capacity and vulnerability is inversely proportional, if the capacity is more, the vulnerability is lower, on the contrary, when the capacity is lower, the vulnerability is getting higher. For this reason, it is necessary to improve the people capability living in landslides prone areas, the capability of $K S B$ as a local organization cares for disaster handling, and the village government on facing the threat of landslides.

\section{CONCLUSION}

Dano Village, Leles District, Garut Regency is a village located in the southern slopes of Mount Guntur, with an altitude between 1200 - $1300 \mathrm{~m}$ asl (above sea level). Most of the Dano Village area is a mountain slope with the slope between 200 - 450. Its eastern anchor is just bordered by natural fence known as the boundary with Lembang Village, Leles District and bordered by Ciharus River on the south which is the administrative boundary to Perhutani area of Mount Guntur. Dano Village, where most of the area is in the form of mountain slopes is unavoidly vulnerable of landslides and potential losses including fatalities, property, damaged facilities and infrastructure, disruption of public activities and services also environmental damage in case there are no prevention, mitigation, preparedness and early warning.

Generally, the research respondents were administrators and members of Disaster Preparedness Village $(K S B)$, both who lived in disaster-prone areas and elsewhere. Most of the male respondents generally have a formal primary school education background, and most of them are in the range of 20 to 30 years. Objects that are likely to be threatened by landslides in Dano Village consists of residences, worship places, school buildings, road infrastructures, bridges, gardens, rice fields, fish ponds, electricity network facilities, livestock, life safety, residents vehicles, school/learning activities, work/livelihood activities, and irrigation facilities. The result of respondent answer calculation shows that landslides threat in Dano village has a high category.

Generally, objects that are prone to landslides in Dano Village include residences, worship places, school buildings, infrastructure roads, bridges, gardens, rice fields, fish ponds, electricity network facilities, livestock, life safety, residents' vehicles, school/learning activities, work/livelihood activities, and irrigation facilities.

The answers calculation result show that Dano Village has a high category of landslides vulnerability.

The ability to deal with a landslides threat in Dano Village, Leles District, Garut Regency related to the various resources 
they can use in dealing with the threat of disaster. These resources consist of knowledge, economic capacity, capabilities in the form of equipment, logistic capabilities, and the ability to recover from disasters, both community capacity, Disaster Preparedness Village organization, and the capacity of village governments.

The calculation results of respondent answers to the recipe for disaster management capability obtained a total score of 1.406. This number shows the ability is in medium category. In general, landslides risk in Dano Village, Leles District, Garut Regency is in low category, this is based on calculation results of the threat value, vulnerability and capability values of the community, Disaster Preparedness Village organization, and the village government. However, although the risk of a disaster is in low to medium category, it is still necessary to do various efforts in order to reduce the risk, especially those related to life safety of people who live in landslides prone areas.

\section{REFERENCES}

Anonim, 2018. "Buku Data Desa Dano Tahun 2018" Kecamatan Leles, Kabupaten Garut.

Abarquez, \& Murshed. (2004). Communitybased disaster risk management: Field practitioners handbook. Bangkok: ADPC. Affeltranger, B., Alcedo, \& Ammann. (2007). Living with risk: a global review of disaster reduction initiatives (2nd ed.). Jakarta: ISDR.

Badan Nasional Penangulangan Bencana. (2010). Rencana aksi nasional penangulangan bencana 2010 - 2012 . Jakarta: BNPB.

Coburn, A. W., \& Spence, R. J. S. (2004). Mitigasi bencana (2nd ed.). The Oast House, Malting Lane, Cambridge, United
Kingdom: Cambridge Archiectural Research Limited.

Coppola, Damon P. (2015). Introduction to international disaster management, third edition. Amsterdam: Elsevier

Khambali, I., \& ST, M. (2017). Manajemen Penanggulangan Bencana. Penerbit Andi.

Lopez, Alejandro. (2014). Disaster Management: International lessons in risk reduction, response and recovery. London: Routledge.

Miles, M. B., \& Huberman, A. M. (1984). Qualitative data analysis: A sourcebook of new methods (2nd ed.). London: Sage Publications.

Nasikun. 2001.. Isu dan Kebijakan Penanggulangan Kemiskinan. Diktat Mata Kuliah. Magister Administrasi Publik Universitas Gadjah Mada. Yogyakarta.

Noor, D. (2014). Pengantar Mitigasi Bencana Geologi. Yogyakarta: Deepublish.

Pujiono. (2004). Model Pedoman Umum Penanggulangan Bencana. Jakarta: Masyarakat Penanggulangan Bencana Indonesia.

Pusat Vulkanologi dan Mitigasi Bencana Geologi (PVMBG). (2007). Daerah rawan gertan Jawa Barat. http://vsi.esdm.go.id

Reduction, U.N. (2015, March, 18) Sendai Framework For Disaster Risk Reduction 2015-2030. Diambil kembali dari United Nations Disaster Risk Reduction : udrr.org

Rogge, M. E. (2004). The future is now: Social work, disaster management, and traumatic stress in the 21st century. Journal of Social Service Research, 30(2), $1-6$

Sarwono, J. (2015) Rumus-Rumus Populer dalam SPSS 22 untuk Riset Skripsi. Yogyakart : Andi.

Streeter, C. L. (2006). Research on social work and disasters (Susan A Murty Ed.). New York: The Hawort Press. Inc

Suharto, E., Azman, A., \& Baba, I. (2011). Pendidikan dan praktik pekerjaan sosial di Indonesia dan Malaysia. Yogyakarta: 
Samudra Biru.

Suharto. (2005). Membangun masyarakat memberdayakan rakyat: kajian strategis pembangan kesejahteraan social dan pekerjaan sosial. Bandung: Refika Aditama

Suharyadi. (2006). Pengantar geologi teknik. Yogyakarta: Biro Penerbit Universitas Gajah Mada.

Supirin. (2004). Pelestarian sumber daya tanah dan air. Yogyakarta: Andi Yogyakarta

UNDRO. (1992). Tinjauan umum managemen bencana (2nd ed.). Jakarta: UNDP.

UNISDR. (2016). Report of the open-ended intergovernmental expert working group on indicators and terminology relating to disaster risk reduction. Geneva ; General Assembly

The United Nations Office for Disaster Risk Reduction (UNISDR). 2015. Sendai Framework for Disaster Risk Reduction 2015-2030. Ganeva, Switzerland: The United Nations Office for Disaster Risk Reduction. Diakses pada 1 Agutus 2020 (www.unisdr.org).

Yayasan IDEP (2005). Panduan umum penanggulangan bencana berbasis masyarakat. Jakarta: Bakornas PBP.

Zakour, M. J., \& Harrel, E. B. (2003). Access to disaster services: social work interventions for vulnerable populations. Journal of Social Service $\begin{array}{lll}\text { Research, } & 30(2), & 27\end{array}$ 